\title{
Importance of ticks in the transmission of zoonotic agents
}

\section{Importancia de las garrapatas en la transmisión de agentes causantes de zoonosis}

\author{
Oscar Betancur H, ${ }^{1 *}$ Ph.D, Antonio Betancourt E, ${ }^{2}$ Ph.D, Cristian Giraldo R, ${ }^{2}$ MVZ. \\ ${ }^{1}$ Elanco Animal Health, Transversal 18 No 96-41. Piso 6, Bogotá D.C., Colombia. ${ }^{2}$ Investigador independiente. \\ *Correspondence: betancur_oscar_jaime@elanco.com
}

Received: March 2015; Acepted: July 2015.

\begin{abstract}
The pathogens transmitted by ticks to human beings are a motive of public health concern around the world, such is the case of Lyme disease in the northern hemisphere, Encephalitis virus in Europe, the recurrent fevers and the Rocky Mountains spotted fever, better known in Colombia as "Tobia Fever". People of all economic and social conditions are prone to develop a zoonotic agent transmitted by these vectors, which could be infected by several pathogens through co-infection mechanisms. The epidemiology and prevalence of these diseases are affected by ecological, climatic and anthropogenic factors. All these factors, affect in a different manner the enzootic cycle between pathogens, ticks and wild hosts. Current molecular diagnostic tools have allowed to progress in pathogen identification, previously unknown or undetermined. The government intervention capacity of each country, and the multidisciplinary professional cooperation, especially from physicians and veterinarians, is fundamental in order to strategically implement control and prevention plans that can deal with this problematic. The present article aims to make a thorough review of the factors which are favoring the transmission of zoonotic agents by ticks, contextualizing the most important aspects that determine their prevalence, and the most relevant control and prevention measures.
\end{abstract}

Key words: Diseases, hosts, pathogens, public health, vectors (Sources: CAB, IEDCYT).

\section{RESUMEN}

Los patógenos transmitidos por garrapatas a los seres humanos son motivo de preocupación para la salud pública alrededor del mundo; tal es el caso de la enfermedad de Lyme en el hemisferio norte, el virus de la encefalitis en Europa, las fiebres recurrentes y la fiebre manchada de las montañas rocosas, conocida en Colombia como la "Fiebre de Tobia". Las personas de todas las condiciones económicas y sociales son susceptibles de contraer un agente zoonótico transmitido por estos vectores, pudiendo ser infectadas incluso por varios patógenos a través de mecanismos de coinfección. La epidemiología y la prevalencia de estas enfermedades se ven afectadas por factores ecológicos, climáticos y antropogénicos. Todos estos factores comprometen de diferente manera el ciclo enzoótico entre patógenos, garrapatas y hospederos silvestres. Las herramientas actuales de diagnóstico molecular han permitido avanzar en la identificación de patógenos anteriormente desconocidos o indeterminados. La capacidad de intervención de los gobiernos de cada país, y la cooperación multidisciplinaria de profesionales, especialmente de médicos y veterinarios es fundamental para implementar planes 
de control y prevención estratégicos que enfrenten esta problemática. El presente artículo pretende hacer una amplia revisión de los factores que están favoreciendo la transmisión de agentes causantes de zoonosis por las garrapatas, contextualizando los aspectos más importantes que determinan su prevalencia, y las medidas de prevención y control relevantes.

Palabras clave: Enfermedades, hospedadores, patógenos, salud pública, vectores (Fuentes: $C A B$, IEDCYT).

\section{INTRODUCTION}

Zoonoses are diseases and infections naturally transmitted between vertebrate animals and humans. The transmission can be direct, or indirect, by means of vectors (1). Close to $60 \%$ of pathogens recognized as causing human disease are zoonotic (2) and the amount of diseases of this type tend to increase (3).

The increase in the appearance of zoonotic pathogens transmitted through ticks is a serious threat to public health worldwide, due to its morbidity and mortality in humans (4). Those of special concern are those that appear for the first time in a population (emergent), or those that have existed and have been labeled under control or extinct, but that quickly increase their prevalence (re-emerging) $(2,3)$. Due to the impact of these diseases on the human population for many decades, the World Health Organization (WHO) and the Pan American Health Organization (PAHO) have formulated guidelines and recommendations in order to advise countries about control of zoonoses (5).

According to Vega (3), it is difficult to know the precise situation of the zoonoses in Colombia because there is no monitoring system designed for such ends; only the casuistry of some zoonoses that are considered priority to the country is gathered; besides, many of the reports of infection are based on the detection of antibodies and, thus, should be considered with caution.

In the present review it is intended to contextualize the factors that facilitate the transmission of tick-borne zoonotic agents, and the key factors that determine its prevalence, as well as the most relevant measures of prevention and control.

Ticks as vectors of zoonotic agents. Only after mosquitos, ticks are considered to be the most important vectors of infectious agents worldwide (6). They are found thoroughly distributed, but their prevalence is greater in countries with warm and humid climates (7). The majority of species of ticks occupy habitats such as forests, savannahs, grasslands and

\section{INTRODUCCIÓN}

Las zoonosis son enfermedades e infecciones naturalmente transmitidas entre animales vertebrados y humanos. La transmisión puede ser directa, o indirecta a través de vectores (1). Cerca del $60 \%$ de los patógenos reconocidos como causantes de enfermedad humana son zoonóticos (2), y la cantidad de enfermedades de este tipo tiende a aumentar (3).

El incremento en la aparición de patógenos zoonóticos transmitidos por garrapatas es una seria amenaza para la salud pública en todo el mundo, por su morbilidad y mortalidad en seres humanos (4). Son de especial importancia aquellas que aparecen por primera vez en una población (emergentes), o aquellas que han existido y se han considerado bajo control o extintas y que rápidamente incrementan su prevalencia (reemergentes) $(2,3)$. Debido al impacto de estas enfermedades en la población humana, desde hace algunas décadas, la Organización Mundial de la Salud (OMS) y la Organización Panamericana de la Salud (OPS) han formulado directrices y recomendaciones para orientar a los países en el control de las zoonosis (5).

Según Vega (3), es difícil conocer la situación exacta de las zoonosis en Colombia porque no hay un sistema de vigilancia diseñado para tal fin; sólo se recoge la casuística de algunas zoonosis, consideradas prioritarias para el país; además, muchos de los reportes de infección, son basados en detección de anticuerpos y, por lo tanto, deben ser tomados con cautela.

En la presente revisión se pretende contextualizar sobre los factores que favorecen la transmisión de agentes causantes de zoonosis por las garrapatas, $y$ los aspectos de mayor importancia que determinan su prevalencia, así como las medidas de prevención y control de mayor relevancia.

Las garrapatas como vectores de agentes causantes de enfermedades zoonóticas. Las garrapatas se consideran, después de los mosquitos, los vectores más importantes de agentes infecciosos en todo el mundo (6). Se encuentran ampliamente distribuidas, pero la prevalencia es mayor en países con climas cálidos y húmedos (7). La mayoría de especies de garrapatas ocupan hábitats como bosques, sabanas, pastizales y matorrales, en los 
scrublands, in which they can survive long periods of time until they find a host on which to feed (8).

Ticks are arthropods belonging to the Arachnid class (9). They are a diverse group, with at least 896 recognized species, distributed into three families: Argasidae or "soft ticks" (193 spp), Ixodidae or "hard ticks" (702 spp), and only one species belonging to the Nuttalliellidae family (10).

Ticks are important vectors of various pathogenic bacteria, such as protozoans and viruses that cause diseases in animals and humans (11). These microorganisms have evolved to take advantage of the life cycle of ticks, using them as a means to disperse from one vertebrate host to another (8). The life cycle of ticks, which include consumption of host blood, the secretion of saliva into the tissue of the host, the movement between different hosts, and the production of eggs from which a new generation of ticks develops that inevitably makes them an adequate home for other organisms (12).

Transmission of pathogens. Some species of ticks can transmit pathogens from wild animals (for example, rodents) to humans (9); the transmission can also be made through domestic animals (7). The risk of transmission is determined by the prevalence of ticks in the environment and by the probability of an encounter between an infected tick and a susceptible host (9).

The transmission of pathogens requires, in the first place, that during feed-uptake, the tick acquires the pathogens of an infected vertebrate host (13). Ticks also can transmit infectious agents from an infected tick to another by co-feeding at the same site in the host, even when the latter is not infected (14); transovarial and/or trans-stadial transmission is an important trait (15). Evolutionally, ticks have developed a protective response to limit levels of pathogen infection, which contribute to their survival (16).

Secondly, pathogenic agents must survive to the development and change between stages of the tick, and become established in the salivary glands of the tick for transmission during the next feeding (13). In this way, some studies indicate that the prevalence of infection in ticks by pathogenic agents is reduced dramatically when there is a change of stage in the tick (15). que pueden esperar largos periodos de tiempo hasta encontrar un hospedero para alimentarse (8).

Las garrapatas son artrópodos pertenecientes a la clase Arachnida (9). Son un grupo diverso, con al menos 896 especies reconocidas, distribuídos en tres familias: Argasidae o "garrapatas blandas" (193 spp), Ixodidae o "garrapatas duras" (702 spp), y solo una especie perteneciente a la familia Nuttalliellidae (10).

Las garrapatas son importantes vectores de varias bacterias patógenas, así como protozoos y virus que causan enfermedades en animales y humanos (11). Estos microorganismos han evolucionado para aprovechar el ciclo de vida de las garrapatas, usándolas como un vehículo para la dispersión de un hospedador vertebrado a otro (8). El ciclo de vida de las garrapatas que incluye el consumo de sangre en los hospedadores, la secreción de saliva en los tejidos del hospedero, el movimiento entre diferentes hospedadores y la producción de huevos a partir de los que se desarrolla una nueva generación de garrapatas, inevitablemente hace que sean adecuadas para albergar otros organismos (12).

Transmisión de patógenos. Algunas especies de garrapatas pueden transmitir los patógenos desde animales silvestres (por ejemplo, roedores) a los seres humanos (9); la transmisión también puede darse a través de los animales domésticos (7). El riesgo de transmisión está determinado por la prevalencia de garrapatas en el ambiente y por la probabilidad de un encuentro entre una garrapata infectada y un hospedador susceptible (9).

La transmisión de patógenos requiere, en primer lugar, que la garrapata durante la alimentación adquiera los patógenos de un hospedador vertebrado infectado (13). Las garrapatas también pueden adquirir los agentes infecciosos desde una garrapata infectada a otra que no lo está por coalimentación en el mismo sitio en el hospedador, aún cuando este último no se encuentre infectado (14); la transmisión transovárica o transestadial es una propiedad importante (15). Evolutivamente, las garrapatas han desarrollado una respuesta protectiva para limitar los niveles de infección de patógenos, lo que contribuye a su supervivencia (16).

En segundo lugar, los agentes patógenos deben sobrevivir al desarrollo y la muda entre estados de la garrapata, y deben establecerse en las glándulas salivales de la misma para su transmisión en la próxima alimentación (13). En este sentido, algunos estudios indican que la prevalencia de la infección de garrapatas por agentes patógenos se reduce drásticamente cuando se produce un cambio de estado (muda) de la garrapata (15). 
Finally, hosts should be competent enough to allow the establishment, the replication and the survival of the infected agents (13). Hosts normally acquire the infection through infected saliva when the ticks are feeding, but in addition, other routes of transmission include infection through the consumption of infected ticks, the manipulation of the tissue of dead infected animals, inhalation, ingestion of non-pasteurized milk and artificial infection through blood transfusion, this latter transmission being of special attention in human and veterinary medicine (12).

Many ticks can house two or more infected agents and transmit them simultaneously (14, 17). This phenomenon is especially frequent in the species of tick known as Ixodes ricinus, which has non-specific feeding habits and feeds on a great variety of vertebrate species that are reservoirs for multiple pathogens $(18,19)$. Alternatively, hosts can be coinfected when bitten by different ticks and at different times (12). Co-infection with multiple pathogens occurs frequently, which causes a serious challenge for adequate diagnosis and treatment (18). On the other hand, even though some pathogens can be transmitted by the same tick (example, Borrelia burgdorferi sensu lato, Anaplasma phagocytophilum and Rickettsia helvetica), they have different ecological cycles and transmission patterns that influence the prevalence of the infection in the different life stages of the tick (20).

Most important pathogens causing tickborne zoonoses. Worldwide, the number of different and epidemiologically important diseases recognized as caused by tick-borne pathogens has considerably increased during the las 30 years (16). For example, Lyme disease in North America and Europe (21); the encephalitis virus transmitted by ticks in Europe and Asia; relapsing fevers in Africa, North America, Europe and Asia (22); and the Rocky Mountain spotted fever in all of the America, known in Colombia as the "Tobia Fever", all have recorded instances of fatality (23).

In Europe, ticks are the principle vectors of zoonotic agents (24), which present a challenge for public health because of its great impact on human health and world economy (8). Some important zoonotic agents transmitted by ticks can be found in tables 1,2 and 3 .
Finalmente, los hospederos deben ser competentes para permitir el establecimiento, la replicación y la supervivencia de los agentes infecciosos (13). Los hospedadores adquieren normalmente la infección a través de la saliva infectada durante la alimentación de las garrapatas, pero además, otras rutas de transmisión incluyen la infección por el consumo de garrapatas infectadas, la manipulación post sacrificio de tejidos de animales infectados, la inhalación, la ingestión de leche no pasteurizada y la infección artificial a través de la transfusión de sangre, esta última de especial atención en medicina humana y veterinaria (12).

Muchas garrapatas pueden albergar dos o más agentes infecciosos y transmitirlos de forma simultánea $(14,17)$. Este fenómeno es especialmente frecuente en especies de garrapatas como Ixodes ricinus, que tienen hábitos alimentarios no específicos y se alimentan de una gran variedad de especies de vertebrados que son reservorios de múltiples patógenos $(18,19)$. Alternativamente, los hospedadores pueden ser coinfectados por mordeduras de diferentes garrapatas y en diferentes momentos (12). La coinfección con múltiples patógenos se produce con frecuencia, lo que plantea un serio desafío para el diagnóstico y tratamiento adecuado (18). Por otro lado, aunque algunos patógenos puedan ser transmitidos por la misma garrapata (ejemplo, Borrelia burgdorferi sensu lato, Anaplasma phagocytophilum y Rickettsia helvetica), tienen diferentes ciclos ecológicos y patrones de transmisión que influyen en la prevalencia de la infección en las diferentes etapas de la vida de una garrapata (20).

Patógenos causantes de zoonosis más importantes transmitidos por garrapatas. A nivel mundial, el número reconocido de enfermedades distintas y epidemiológicamente importantes causadas por patógenos transmitidos por las garrapatas ha aumentado considerablemente durante los últimos 30 años (16). Por ejemplo, la Enfermedad de Lyme en Norte América y Europa (21); el virus de la encefalitis transmitido por garrapatas en Europa y Asia; las fiebres recurrentes en África, Norte América, Europa y Asia (22); y la fiebre manchada de las montañas rocosas en toda América, conocida en Colombia como la "Fiebre de Tobia", donde se han presentado casos fatales (23).

En Europa, las garrapatas son los principales vectores de agentes causantes de zoonosis (24), lo que representa un reto para la salud pública por el enorme impacto en la salud humana y en la economía en el mundo (8). Algunos agentes zoonóticos importantes transmitidos por garrapatas pueden encontrarse en las tablas 1,2 y 3 . 
Table 1. Zoonotic bacteria transmitted by ticks around the world.

\begin{tabular}{|c|c|c|c|}
\hline ZOONOSIS & TRANSMITTED PATHOGEN & TICK VECTOR & REF \\
\hline \multirow[t]{2}{*}{ Human granulocytic anaplasmosis } & $\begin{array}{c}\text { Anaplasma } \\
\text { phagocytophilum }\end{array}$ & $\begin{array}{l}\text { Ixodes scapularis Ixodes pacificus, Ixodes persulcatus, } \\
\text { Ixodes ricinus }\end{array}$ & $(21)$ \\
\hline & Ehrlichia chaffeensis & Amblyomma americanum & $(22)$ \\
\hline \multirow[t]{2}{*}{ Human monocytic ehrlichiosis } & E. chaffeensis; E. ewingii & Rhipicephalus sanguineus? & (17) \\
\hline & Ehrlichia canis & Rhipicephalus sanguineus & $(25)$ \\
\hline Lyme disease & Borrelia burgdorferi sensu lato & $\begin{array}{c}\text { Ixodes spp. } \\
\text { (I. scapularis; I. pacificus; I. persulcatus; I. ricinus) }\end{array}$ & $(21,22,26)$ \\
\hline Tick-borne African fever & Rickettsia africae & $\begin{array}{l}\text { Amblyomma hebraeum, } \\
\text { Amblyomma variegatum }\end{array}$ & $(22,27)$ \\
\hline Mediterranean spotted fever & Rickettsia conorii & Rhipicephalus sanguineus & $(22,28)$ \\
\hline $\begin{array}{c}\text { Rocky Mountain spotted fever "Tobia } \\
\text { Disease" }\end{array}$ & Rickettsia rickettsii & $\begin{array}{l}\text { Amblyomma cajennense, } \\
\text { Dermacentor andersoni, } \\
\text { Dermacentor variabilis, } \\
\text { Rhipicephalus sanguineus }\end{array}$ & $(9,22)$ \\
\hline Q Fever & Coxiella burnetii & $\begin{array}{l}\text { More than } 40 \text { species of different kinds. Haemaphysalis } \\
\text { spp., and Ixodes spp., (of highest prevalence in } \\
\text { Europe), and Rhipicephalus spp., Amblyomma spp., and } \\
\text { Dermacentor spp., of highest prevalence in America. }\end{array}$ & $(22,29)$ \\
\hline Relapsing fever & Borrelia spp. & Ornithodorus spp. & $(22)$ \\
\hline Tularemia & Francisella tularensis & $\begin{array}{c}\text { Dermacentor andersonii, D. variabilis, D. occidentalis, and } \\
\text { Amblyomma americanum }\end{array}$ & (9) \\
\hline
\end{tabular}

Table 2. Zoonotic viruses transmitted by ticks around the world.

\begin{tabular}{|c|c|c|c|}
\hline Powassan encephalitis & Flavivirus & $\begin{array}{l}\text { Ixodes spp. (I. cookei, I. marxi, I. spinipalpus, I. } \\
\text { persulactus), Dermacentor spp. (D. andersoni, D. } \\
\text { silvarum), y Haemaphysalis sp (H. longicornis) }\end{array}$ & $(1)$ \\
\hline Tick-borne encephalitis & Flavivirus & Ixodes spp. (I. ricinus; $I$. persulcatus) & $(1,22)$ \\
\hline Kyasanur forest disease & Flavivirus & Haemaphysalis spinigera & $(1,22)$ \\
\hline Colorado tick fever & Coltivirus & Dermacentor andersoni & $(22,30)$ \\
\hline Omsk hemorrhagic fever & Flavivirus & $\begin{array}{l}\text { Dermacentor marginatus, } \\
\text { D. reticulatus, Ixodes persulcatus }\end{array}$ & $(1,22)$ \\
\hline Crimean-Congo haemorrhagic fever & Nairovirus & Hyalomma marginatum & $(22,31)$ \\
\hline $\begin{array}{l}\text { Thrombocytopenia syndrome with } \\
\text { severe fever }\end{array}$ & Flebovirus & Haemaphysalis longicornis & $(32)$ \\
\hline Langat Virus & Flavivirus & Ixodes granulatus, I. persulcatus; Haemaphysalis papuana & (1) \\
\hline Tyuleniy Virus & Flavivirus & Ixodes uriae & (1) \\
\hline
\end{tabular}

Table 3. Zoonotic parasites transmitted by ticks around the world.

\begin{tabular}{ccc}
\hline Babesiosis & Babesia microti & Ixodes scapularis \\
& B. divergens; & Ixodes ricinus \\
B. venatorum (EU1-3), B WA1, & B MO1, B CA1, B TW1 & (33) \\
\hline Ixapularis
\end{tabular}

REF: reference 
Ecological factors associated with tickborne zoonotic agents (TBZA). TBZAs typically appear because of interference in circulation between animals, wild reservoirs and ticks (12). Even though it is considered that wild animals are the principle reservoirs of various pathogens that cause disease in humans, for some TBZAs, domestic animals can eventually become important reservoirs for human pathogens (34).

The displacement of ticks is limited, and they cannot be displaced over great distances without the help of a vertebrate that acts as a mechanical vector with which ticks can cross natural boundaries and be dispersed over mountain chains, islands and bodies of water (35); ticks also colonize new territories when mechanical vectors are introduced by humans in new areas (12). After arriving to a new territory, the survival of the ticks is limited by the presence of other competitors, predators and the availability of hosts (35).

The most competent natural reservoirs for some tick-borne pathogens are hosts that tend to have high population densities and rapid life cycles (36); such as rodent and birds (20). In the same way, rodents constitute one of the most important hosts for ticks, especially for larvae and nymphs. Nonetheless, the microclimatic conditions of a particular zone can affect contact between ticks and rodents, which can influence the selection of new hosts (37).

For their part, birds have be found to be carriers of some species of ticks (16), in which case migratory birds are particularly important, since the presence of Bartonella spp. (38), Anaplasma sp., Borrelia sp., and Rickettsia sp., have already been proven in ticks obtained from birds (39). Birds are not simple mechanical vectors; they can develop an infection, which converts them into active pathogen hosts, for example, the developing of bacteremia such as Rickettsia helvetica and Anaplasma phagocytophilum. The prevalence of tick-borne infestations in birds is associated to a large degree with the habit of ground feeding (40).

Birds have great epidemiological importance due to the fact that they can fly great distances in the course of only a few days (40). Epidemiologic potential is greater because of horizontal transmission of TBZAs between birds that share ecological niches (39).
Factores ecológicos asociados a los agentes zoonóticos transmitidos por garrapatas (AZTG). Los AZTG típicamente se presentan por una interferencia en la circulación entre los animales, reservorios silvestres y las garrapatas (12). Aunque se considera que los animales silvestres son los principales reservorios de varios patógenos que causan enfermedades humanas, para algunos AZTG, los animales domésticos pueden eventualmente emerger como reservorios importantes para patógenos humanos (34).

La capacidad de desplazamiento de las garrapatas es limitada, y no pueden hacerlo por grandes distancias sin la ayuda de un vertebrado que actúe como vector mecánico, con los cuales las garrapatas pueden atravesar barreras naturales para la dispersión, como cadenas montañosas, islas o cuerpos de agua (35); las garrapatas también colonizan nuevos territorios cuando los vectores mecánicos son introducidos en nuevas áreas por los seres humanos (12). Después de llegar a un nuevo territorio, la supervivencia de las garrapatas se ve limitada por la presencia de otros competidores, de depredadores y la disponibilidad de hospedadores (35).

Los reservorios naturales más competentes para algunos patógenos transmitidos por garrapatas son hospedadores que tienden a tener altas densidades de población y ciclos de vida rápidos (36); como roedores y aves (20). En ese mismo sentido, los roedores constituyen uno de los hospedadores más importantes para las garrapatas, especialmente para las larvas y las ninfas. No obstante, las condiciones microclimáticas de una zona en particular pueden afectar el contacto entre garrapatas y roedores, lo que puede predisponer a la selección de nuevos hospedadores (37).

Por su parte, las aves han sido conocidas como portadores de algunas especies de garrapatas (16), lo que cobra especial importancia en el caso de las aves migratorias, ya que se ha comprobado la presencia de Bartonella spp. (38), Anaplasma sp., Borrelia sp., y Rickettsia sp., en garrapatas obtenidas de las aves (39). Las aves no son simples vectores mecánicos; éstas pueden desarrollar una infección, lo que las convierte en hospederos activos de los patógenos, por ejemplo, el desarrollo de bacteremia por Rickettsia helvetica y Anaplasma phagocytophilum. La prevalencia de la infestación por garrapatas en las aves está asociada en gran medida con el hábito de alimentación en el suelo (40).

Las aves tienen una gran importancia epidemiológica debido a que pueden volar grandes distancias en el curso de unos pocos días (40). El potencial epidemiológico es mayor por la posibilidad de transmisión horizontal de los AZTG entre aves que comparten nichos ecológicos (39). 
The increase in interaction between wild and domestic animals has increased the transmission of ticks to humans (7). In regards to canines, they can serve as reservoirs for human pathogens, as definitive hosts or mechanical transporters of ticks, and as sentinel indicators of regional disease risk (9). Although the majority of species of ticks are of a singular host, the introduction of infected larvae and nymphs to a home can cause the transmission of pathogens to humans after the tick's change of stage inside the house. On the other hand, the introduction of an engorged female can facilitate the establishment of a population of ticks inside the home, some of which are able to successfully adapt to the conditions of human residences (as $R$. sanguineus) (34).

\section{Anthropogenic factors associated with} TBZAs. One would think that humans were one of the most common food sources for ticks having in mind the huge size of human population in the world, its great density in some areas, and the size of a human adult's body; however, they are not important reservoirs for TBZAs, although ticks can potentially cause sickness in a great number of individuals, such episodes typically are an accident (12).

Over a long period of time, all countries have experienced important changes in their epidemiological profile as a result of social, economic and cultural transformations (5). In recent years, many factors have changed the interactions between humans, animals and the environment, which has caused the emergence and re-emergence of many diseases (7). The appearance of AZTGs is becoming an increasing problem due to the intensification of migrations of humans and animals, and environmental changes (18). In effect, human populations are growing and expanding in new geographic areas, invading wild ecological niches and facilitating the transmission of pathogens to humans (41).

The emergence of tick-borne zoonotic diseases is associated with changes in the use of the soil, which obligate pathogens and ticks to find new transmission mechanisms associated with humans; on the other hand, the population's social economic conditions also facilitate the emergence of these diseases; the risk is greater for people with high and low incomes than those of the middle class. For example, people of higher income look for country homes near forests (42), or they have the possibility of travelling to previously inaccessible places;
El aumento de las interacciones de los animales salvajes con los animales domésticos, ha aumentado la transmisión de garrapatas hasta los seres humanos (7). En el caso de los perros, pueden servir como reservorios de patógenos humanos, como hospedadores definitivos o transportadores mecánicos de garrapatas, y como indicadores centinela de riesgo de enfermedad regional (9). Aunque la mayoría de especies de garrapatas son de un solo hospedador, la introducción de larvas y ninfas infectadas en una casa puede provocar la transmisión de patógenos a seres humanos después del cambio de estadío de la garrapata dentro de la casa. Por otra parte, la introducción de hembras ingurgitadas puede permitir el establecimiento de una población de garrapatas dentro de la casa, algunas de las cuales logran adaptarse exitosamente a las condiciones de las viviendas (como $R$. sanguineus) (34).

Factores antropogénicos asociados a los AZTG. Se esperaría que los seres humanos fueran una de las fuentes de alimento más comunes para las garrapatas teniendo en cuenta el gran tamaño de la población humana en el mundo, la alta densidad en algunas áreas, y el tamaño del cuerpo humano adulto; sin embargo, estos no son importantes reservorios de los AZTG y, aunque potencialmente pueden causar enfermedad en un gran número de individuos, tales episodios son típicamente un accidente (12).

Todos los países han presentado a lo largo del tiempo, cambios importantes en su perfil epidemiológico, como resultado de las transformaciones sociales, económicas y culturales (5). En los últimos años, muchos factores han cambiado las interacciones entre los seres humanos, los animales y el medio ambiente, lo que ha provocado la emergencia y reemergencia de muchas enfermedades (7). La aparición de AZTG se está convirtiendo en un problema cada vez mayor debido a la intensificación de las migraciones de humanos y animales, y a los cambios ambientales (18). En efecto, las poblaciones humanas están creciendo y expandiéndose en nuevas áreas geográficas invadiendo nichos ecológicos silvestres, facilitando la transmisión de patógenos al ser humano (41).

La emergencia de las enfermedades zoonóticas causadas por agentes transmitidos por garrapatas se asocia con cambios en el uso de la tierra, que obligan a los patógenos y garrapatas a encontrar nuevos mecanismos de transmisión asociados con el desarrollo humano; por otro lado, las condiciones socioeconómicas de la población también favorecen la emergencia de estas enfermedades; ésto puede ser mayor en las personas de ingresos altos y bajos que en aquellos con ingresos intermedios. Por ejemplo, las personas de altos ingresos buscan 
in addition, the popularity of out-door activities such as hiking and fishing has increased (14). On the other hand, economically disadvantaged people can be less protected against infection (because of malnutrition or immune suppression). In addition, access to available vaccines for some AZTGs, which are usually expensive, is limited (43).

Climatic factors associated with TBZAs. Without a doubt, climate change has a strong impact on the dynamics of infectious diseases (5). Climate directly affects the livelihood of ticks (16) and can also indirectly affect them through the effect it has on vegetation and hosts, as much in terms of abundance as survival (26).

Microclimatic variables such as the temperature of ground surface and relative humidity can be crucial in determining the distribution pattern of specific niches and the survival of ticks in a given area (26). The abundance of ticks is greater in lower altitudes, where the climate is warmer. At high altitudes where the temperatures are lower, ticks are less active, which reduces their access to hosts, because of which they can have a lesser probability of survival than ticks in low altitudes (24). The decreased activity of ticks in cold environments lowers pathogen transmission (16).

Climate change can facilitate the migration of vertebrate hosts, which permits the spread of ticks and pathogens to new territories (12); because of weather changes, these new areas can be transformed into favorable habitats for ticks (for example, the warmest temperatures in the highest elevations or latitudes) (9). Another point-of-view indicates that, although climate change can result in adequate climate conditions in some places, these zones will remain free of the disease unless all components of the system (host, vector and pathogen) arrive and are simultaneously sustained in these locations during a period of time sufficient for establishing transmission cycles (35).

In common with almost all arthropods, development rates of ticks increases with the rise of temperature (13). Specifically, the highest temperatures raise three fundamental aspects: the vector's bite rate, development rate and the rate of pathogen replication; none the less, frequently they diminish the survival of the vector, especially when it is associated with a lack of humidity (42). The combined effects of temperature and humidity influence the behavior, survival and reproduction of vivir en casas campestres cerca de bosques (42), o tienen la posibilidad de viajar a lugares previamente inaccesibles del planeta; además ha crecido la popularidad de actividades al aire libre como el senderismo y la pesca (14). Por el contrario, las personas económicamente desfavorecidas pueden estar menos protegidas contra una infección (por desnutrición, inmunodepresión). Sumado a esto, el acceso a las vacunas disponibles para algunos de los AZTG, las cuales suelen ser costosas, es limitado (43).

Factores climáticos asociados a los AZTG. Sin duda, el cambio climático incide con fuerza en la dinámica de las enfermedades infecciosas (5). El clima afecta directamente la capacidad de subsistencia de las garrapatas (16); y también puede indirectamente afectarlas por los efectos directos sobre la vegetación y los hospederos, tanto en términos de abundancia como de supervivencia (26).

Las variables microclimáticas como temperatura de la superficie del suelo y la humedad relativa pueden ser cruciales para determinar el patrón de distribución de nichos específicos y supervivencia de las garrapatas dentro de un área (26). La abundancia de garrapatas es mayor a menor altitud, donde el clima es más cálido. A grandes altitudes donde las temperaturas son bajas, las garrapatas son menos activas, lo cual reduce el acceso a los hospedadores, por lo que pueden tener una menor probabilidad de supervivencia que las garrapatas a baja altura (24). La menor actividad de las garrapatas en ambientes fríos también disminuye la transmisión de patógenos (16).

El cambio climático puede facilitar la migración de los vertebrados hospederos de garrapatas, lo que permite la dispersión de estas y de patógenos a nuevos territorios (12); estas nuevas áreas pueden por efecto de las modificaciones climatológicas, haberse transformado en hábitats favorables para las garrapatas (por ejemplo, las temperaturas más cálidas en las elevaciones más altas o latitudes superiores) (9). Otro punto de vista indica que, aunque el cambio climático podría resultar en condiciones climáticas adecuadas en algunos lugares, estas zonas se mantendrán libres de la enfermedad a menos que todos los componentes del sistema (hospedador, vector, patógenos) lleguen y se sostengan simultáneamente en estos sitios durante el tiempo suficiente para establecer los ciclos de transmisión (35).

En común con casi todos los artrópodos, las tasas de desarrollo de las garrapatas incrementan al aumentar la temperatura (13). En concreto, las temperaturas más altas aumentan tres aspectos fundamentales: la tasa de mordedura del vector, la tasa de desarrollo de vectores y la tasa de replicación del patógeno; sin embargo, con frecuencia también disminuyen 
many species of vectors. The same conditions limit the ability of ticks to find hosts in exposed environments (35). In addition, relatively prolonged periods of high temperatures and low humidity can interrupt the enzootic cycle of some tick-borne pathogens, for example that of tick-borne encephalitis (37).

Although the impact of climate change has been supported on the basis of the rise in temperature, the potential influence of changes in rainfall patterns has frequently been ignored, even when this could have a greater effect than temperature on the ability of tick populations to establish themselves in new zones (16)

Diagnosis. The prevalence or the report of zoonotic diseases from tick-borne pathogens has increased in the past years, in great measure because of advancements made in diagnostic tools, especially in molecular techniques which have permitted laboratories to increase the ability of detecting new pathogens and distinguish between microorganism species and strains (12). Techniques such as the polymerase chain reaction (PCR) have allowed simultaneous identification of different types of viruses, in addition to bacteria that are difficult to grow in traditional culture mediums, or that have been found in samples that have been treated with antibiotics. Nonetheless, the use of serology, cultures and histopathology among others, continue to be tools of vital importance in identifying zoonotic agents (44).

However, the diagnostic ability of some countries like Colombia can be limited, where an adequate network of zoonosis detection laboratories that facilitate the adequate process and the confirmation of these diseases is lacking; also, diagnostic and epidemiological methods are unknown (3). In the same way, it is presumed that some cases of zoonosis are processed sub-clinically and thus never diagnosed (45).

On the other hand, important advances in epidemiology studies have been made. The use of multivariate analysis has facilitated a better understanding of all the components that are part of the complex cycles involving ticks, reservoirs, and pathogens (35).

Multi-parametric models have made it possible to predict and estimate changes in geographic distribution areas of ticks (12). The most commonly used strategy for estimating the potential geographic distribution area of a species is the characterization of environmental la supervivencia del vector, especialmente cuando se asocia con la falta de humedad (42). Los efectos combinados de la temperatura y la humedad afectan el comportamiento, la supervivencia y reproducción de muchas especies de vectores. Las mismas condiciones limitan la capacidad de las garrapatas de buscar hospedadores en ambientes expuestos (35). Además, periodos de altas temperaturas y baja humedad relativa prolongados en el tiempo pueden interrumpir el ciclo enzoótico de algunos patógenos transmitidos por garrapatas, por ejemplo el del virus de la encefalitis transmitido por garrapatas (37).

Aunque el impacto del cambio climático sobre los AZTG se ha sustentado sobre la base del aumento de temperatura, la influencia potencial de los cambios en los patrones de lluvia ha sido frecuentemente ignorada, aún cuando esto puede tener un efecto mayor que la temperatura en la capacidad de las poblaciones de garrapatas de establecerse en nuevas áreas (16).

Diagnóstico. La prevalencia o el reporte de las enfermedades zoonóticas causadas por patógenos transmitidos por garrapatas se ha incrementado en los últimos años, en gran medida por los avances en las herramientas de diagnóstico, especialmente de técnicas moleculares que han permitido a los laboratorios ampliar la capacidad de detectar nuevos patógenos, y distinguir entre especies y cepas de microorganismos (12). Técnicas como la Reacción en Cadena de la Polimerasa (PCR) han permitido la identificación simultánea de diferentes tipos de virus, además de bacterias de difícil crecimiento en medios de cultivo tradicionales, o que se encuentran en muestras que han sido tratadas con antibióticos. Sin embargo, la utilización de serologías, cultivos, histopatología, entre otras, siguen siendo herramientas de vital importancia para la identificación de agentes causantes de zoonosis (44).

No obstante, la capacidad diagnóstica en algunos países como Colombia puede ser limitada, donde se carece de una adecuada red de laboratorios de detección de zoonosis que permita un proceso adecuado y la confirmación de estas patologías. Además, existe un desconocimiento por parte de médicos y veterinarios, de la clínica de estas enfermedades; también se desconocen los métodos de diagnóstico y epidemiológicos (3). Asimismo, es de suponer que algunos de los casos de zoonosis, pueden cursar de manera subclínica y como consecuencia nunca ser diagnosticados (45).

Por otro lado se han logrado avances importantes en estudios epidemiológicos. La utilización de análisis multivariados ha permitido una mejor interpretación de todos los componentes que hacen parte de los complejos ciclos entre garrapatas, reservorios, y patógenos (35). 
conditions that are adequate for the species, and later identifying where the right environment exists (16). Although simple predictions about changes in tick abundance can be made, it is necessary to make similar predictions about the availability of appropriate hosts coinciding with the population increase of ticks over space and time (24).

Control and prevention. Zoonotic diseases caused by tick-borne pathogens can be difficult to control due to the complex epidemiology that involves different ticks and hosts (34). For this reason, the fundamental tool for control is permanent epidemiological monitoring. Programs for control of these diseases requires the integration of data from veterinary and human information systems, the monitoring of wild animals and tick populations, and teams of experts from various scientific disciplines such as entomology, epidemiology, medicine, public health and veterinary medicine (12). Government agencies in charges of public health are fundamental as a base for information for all epidemiological studies (46). A database has been developed that involves ticks as vectors for zoonotic pathogens within a project financed by the European Union, with the collaboration of SAPUVETNET III, in which not only information about this subject is offered, but predictive maps of geographic distribution of ticks and zoonotic diseases caused by tickborne pathogens (4).

Principles, strategies and control and prevention tactics for TBZAs in humans should be adapted to the conditions of each country (3). It is imperative to develop measures of integrated control, which include: vectors control, vaccination programs against tick-borne zoonotic agents, betterment of treatment strategies, improvement of diagnostic and monitoring equipment, and public awareness campaigns (47).

The principal method for controlling ticks is the application of chemical compounds. The problem with this is that it requires frequent reapplication, which is a risk to the health of non-objective, incidentally exposed animals (9). On the other hand, the constant reapplication can cause resistance to the compound; in addition, very little is known about the degree to which biocides and their toxic degradation products are accumulated in predators, scavenger birds, and mammals (8); in the same way, a control strategy based exclusively on the use of acaricides, implies risks to humans because of the danger of deposition of pesticide residues in products
Los modelos matemáticos multiparamétricos han permitido hacer predicciones y estimativos sobre los cambios en las áreas de distribución geográfica de las garrapatas (12). La estrategia más común para estimar el área potencial de distribución geográfica de una especie es la caracterización de las condiciones ambientales que son adecuados para la especie, y después identificar dónde existe el ambiente adecuado distribuido en el espacio (16). Aunque se pueden hacer predicciones simples sobre los cambios en la abundancia de garrapatas, es necesario hacer predicciones similares sobre la disponibilidad de los hospedadores competentes coincidiendo con el aumento de población de garrapatas en el espacio y el tiempo (24).

Control y prevención. Las enfermedades zoonóticas causadas por patógenos transmitidos por garrapatas pueden ser difíciles de controlar debido a la compleja epidemiología que involucra diferentes garrapatas y hospedadores (34). Por ello la herramienta fundamental de control es la vigilancia epidemiológica permanente. Los programas de control de estas enfermedades requieren la integración de datos de los sistemas de información veterinaria y humana, la vigilancia de los animales salvajes y poblaciones de garrapatas, y equipos combinados de expertos de varias disciplinas científicas como la entomología, epidemiología, la medicina, la salud pública y la medicina veterinaria (12). Las entidades gubernamentales encargadas de la salud pública son fundamentales como base de información para todos los estudios epidemiológicos (46). Se ha desarrollado una base de datos que involucra a las garrapatas como vectores de patógenos que causan zoonosis dentro de un proyecto financiado por la Unión Europea, con la colaboración de SAPUVETNET III, en el cual no solo se ofrece información sobre este tema, sino que se están preparando mapas predictivos para distribución geográfica de garrapatas y enfermedades zoonóticas causadas por patógenos transmitidos por garrapatas (4).

Los principios, las estrategias y las tácticas de control y prevención de los AZTG en el hombre deben adaptarse a las condiciones de cada país (3). Es imperativo elaborar medidas de control integrado, que incluyan: el control de vectores, programas de vacunación contra los agentes zoonóticos transmitidos por garrapatas, mejora de las estrategias de tratamiento, mejora de las herramientas de diagnóstico y vigilancia, campañas de sensibilización pública (47).

El principal método para controlar garrapatas, es la aplicación de compuestos químicos. El problema es que se requiere de la reaplicación frecuente, lo cual puede representar riesgos para la salud de los animales no-objetivo incidentalmente expuestos (9). Por otra parte, la reaplicación constante puede promover resistencia a los insecticidas; además, se 
and sub-products of animal origin (such as meat, milk and eggs), in addition to being a contaminate to the environment. The direct application of acaricides to vertebrate hosts of ticks reduces the effects on nonobjective species, but should be included in a strategic control plan (48). This plan should include the rotation of products by action mechanisms of their active ingredients and not by their commercial names, for example organophosphate and pyrethroid insecticides alternated with fluazuron as a quitine inhibitor.

When also turning to non-chemical control as part of an integrated plan, it becomes and important complementary alternative to chemical compounds; normally they are not toxic to non-objective humans or animals, and reduce the risk of forming resistance. These include the use of natural predators of ticks such as insectivorous birds, unfavorable hosts, parasitoid wasps, nematodes, bacteria and entomopathogenic fungi. The latter in particular have proven to be very effective in controlling all types of ticks: Rhipicephalus (Boophilus spp.), and Amblyomma spp. associated with livestock (8).

Human vaccination programs against tickborne zoonotic agents are very effective but have some limitations. On one hand, the cost makes them unavailable to the entire population, making governmental assistance through public health authorities necessary (43); on the other hand, vaccines for the majority of tick-borne pathogens do not exist (32); only some such as tick-borne encephalitis (1) or that of Lyme disease. It is important to understand that vaccination against specific pathogens does not omit the need for other measures to prevent tick bites, being that the vaccine does not give cross protection against other TBZAs (9).

Educating pet owners on the implementation of integrated tick control programs could be crucial in reducing the risk of infestation and can decrease the probability of bringing infected ticks into homes. For people who visit or work in environments with tick infestations, the use of tick repellent and acaricide is advised (34).

In summary, preventative measures should be taken and strategic short, medium and long-term control plans should be adopted. The most effective preventative measures are: immunoprophylaxis, if a vaccine exists, and use of protective clothing and repellent. In areas that are natural focal points for sabe muy poco sobre el grado en que los biocidas y sus productos de degradación tóxicos se acumulan en los depredadores, carroñeros de aves y mamíferos (8); en este mismo sentido, la estrategia de control basada exclusivamente en el empleo de acaricidas químicos, conllevaría riesgos en los humanos por el peligro de deposición de residuos de pesticidas en productos y subproductos de origen animal (carne, leche, huevos), además de ser contaminante del ambiente. La aplicación directa de acaricidas a los hospedadores vertebrados de las garrapatas reduce los efectos a especies no objetivo, pero deben hacer parte de un plan estratégico de control (48). Este plan debe incluir la rotación de los productos por los mecanismos de acción de sus principios activos y no por los nombres comerciales, por ejemplo insecticidas organofosforados y piretroides alternados con fluazurón como inhibidor de la quitina.

Cuando adicionalmente se recurre al control no químico como parte de un plan integrado, éste se convierte en una importante alternativa complementaria a los compuestos químicos; normalmente no son tóxicos para los seres humanos y la fauna no objetivo, y reducen el riesgo de resistencia. Estos incluyen el uso de enemigos naturales de las garrapatas como aves insectívoras, hospederos desfavorables, avispas parasitoides, nemátodos, bacterias y hongos entomopatógenos. Estos últimos en particular han mostrado ser muy eficaces para el control de garrapatas de los géneros: Rhipicephalus (Boophilus spp.), y Amblyomma spp. asociadas al ganado (8).

Los programas de vacunación en humanos contra los agentes zoonóticos transmitidos por garrapatas, son muy efectivos, pero presentan algunas limitaciones. Por un lado, el costo hace que no sean accesibles para toda la población, siendo necesario el apoyo gubernamental a través de las autoridades de salud pública (43); por otra parte, no existen vacunas para la mayoría de patógenos transmitidos por garrapatas (32); solo algunas como la del virus de encefalitis transmitida por garrapatas (1) o la de la enfermedad de Lyme. Es importante entender que la vacunación contra un patógeno específico no obvia la necesidad de otras medidas para evitar las mordeduras de garrapatas, ya que la vacuna no confiere protección cruzada contra otros AZTG (9).

Educar a los dueños de mascotas para que implementen programas integrales de control de garrapatas podría ser crucial para reducir el riesgo de infestación y con ello disminuir la probabilidad de llevar garrapatas infectadas a las viviendas. Para las personas que visitan o trabajan en ambientes infestados de garrapatas se aconseja el uso de repelentes de garrapatas o acaricidas (34).

En resumen, se deben tomar todas las medidas de carácter preventivo y adoptar planes estratégicos de 
ticks (such as natural parks, reserves and city suburbs), preventative measures are centered on: establishing barriers for the vector, eliminating feeding sites close to human settlements and applying insecticides to surrounding areas (3). It should be understood that no technique alone is $100 \%$ effective; nonetheless, a program should be chosen that integrates various preventative components to maximize protection against TBZAs (9).

Research perspectives. The Colombian panorama in terms of epidemiological studies regarding TBZAs is large. Demographic expansion in many cases forces invasion into diverse ecological niches; for this reason, organizations that manage land development plans should consider epidemiological studies of all zones that can be focal points of infection; requiring that investigations are made to facilitate the identification of possible TBZAs and risk factors associated with a particular zone.

Activities such as ecotourism, hiking and fishing, among others, can be a risk factor for contracting TBZAs; it is necessary to carry out studies which evaluate risk factors and can implement prevention and control measures in places where these activities are promoted, especially, when the end of the Colombian armed conflict ends in the near future, which will promote in great measure the increase of these forms of entertainment.

Multifactorial studies can be carried out in which the effects on TBZAs on climate change in Colombia are considered, having in mind variables such as temperature, relative humidity and rainfall, in addition to current tick species and the availability of native hosts as well as potential said arthropods. Another possible investigation can be made to assess migratory birds that arrive to Colombia and ticks that they carry, where the role that these vertebrates play in the spread of zoonotic diseases caused by tick-borne pathogens in this nation can be established. control a corto, mediano y largo plazo. Las medidas de prevención más efectivas son: la inmunoprofilaxis, si existe vacuna; uso de ropa protectora y de repelentes. En zonas que son focos naturales de las garrapatas (parques naturales, zonas de reserva, suburbios de las ciudades), las medidas se centran en: establecer barreras para el vector, eliminar sitios de alimentación cercanos al asentamiento humano, aplicar insecticidas en los alrededores (3). Debe entenderse que ninguna técnica por si sola es $100 \%$ eficaz; sin embargo, debe elegirse un programa integrado de varios componentes preventivos para maximizar la protección contra los AZTG (9).

Perspectivas de investigación. El panorama de Colombia en términos de estudios epidemiológicos referentes a los AZTG es amplio. La expansión demográfica obliga en muchas ocasiones a la invasión de diversos nichos ecológicos; por esta razón las entidades encargadas de los Planes de Ordenamiento Territorial deben considerar estudios epidemiológicos de todas las zonas que puedan ser focos de infección; siendo por lo tanto necesaria la realización de investigaciones que permitan identificar los posibles AZTG y los factores de riesgo asociados a alguna zona en particular.

Actividades como el ecoturismo, el senderismo, la pesca, entre otras, pueden ser un factor de riesgo para contraer AZTG; es necesario hacer estudios en lugares en los que se promueven estas actividades donde se evalúen los factores de riesgo y se puedan implementar medidas de prevención y control, sobre todo, cuando en el futuro cercano se vislumbra el final del conflicto armado colombiano, lo que promoverá en gran medida el aumento de éstas formas de entretenimiento.

Podrían realizarse estudios multifactoriales en los que se consideren los efectos del cambio climático en Colombia en los AZTG, teniendo en cuenta variables como la temperatura, humedad relativa, pluviosidad, así como las especies de garrapatas presentes y la disponibilidad de hospedadores nativos y potenciales para dichos artrópodos. Otra posibilidad de investigación se presenta en la valoración de las aves migratorias que llegan a Colombia y las garrapatas que portan, donde se pueda establecer el rol que desempeñan éstos vertebrados en las enfermedades zoonóticas causadas por patógenos transmitidos por garrapatas en esta nación. 


\section{REFERENCES}

1. Dobler G. Zoonotic tick-borne flaviviruses. Vet microbiol 2010; 140(3-4):221-8.

2. Monsalve S, Mattar S, Gonzalez M. Zoonosis transmitidas por animales silvestres y su impacto en las enfermedades emergentes y reemergentes. Rev MVZ Córdoba 2009; $14(2): 1762-73$.

3. Vega RL. Zoonosis emergentes $y$ reemergentes y principios básicos de control de zoonosis. Rev Med Vet Zoot 2009; 17(enero-junio):85-97.

4. Vesco U, Knap N, Grindatto A, AvsicZupanc T, Labruna M, Estrada-Peña A, et al. A database on ticks and tick-borne zoonoses in the (sub-)tropics: an example of intersectoral and institutional collaboration at international level. Una Salud Rev Sapuvet Sal Púb 2010; I(enero-junio):41-8.

5. Agudelo-Suárez AN. Aproximación a la complejidad de las zoonosis en Colombia. Rev Salud Pública 2012; 14(2):325-39.

6. Toledo A, Olmeda AS, Escudero R, Jado I, Valcarcel F, Casado-Nistal MA, et al. Tickborne zoonotic bacteria in ticks collected from central Spain. Am J Trop Med Hyg 2009; 81(1):67-74.

7. Liyanaarachchi DR, Rajakaruna RS, Dikkumbura AW, Rajapakse RP. Ticks infesting wild and domestic animals and humans of Sri Lanka with new host records. Acta Trop 2015; 142(Feb):64-70.

8. Ostfeld RS, Price A, Hornbostel VL, Benjamin MA, Keesing M. Controlling Ticks and Tickborne Zoonoses with Biological and Chemical Agents. BioScience 2006; 56(5):383-94.

9. Fritz CL. Emerging tick-borne diseases. Vet Clin North Am Small Anim Pract 2009; 39(2):265-78.

10. Guglielmone AA, Robbins RG, Apanaskevich DA, Petney TN, Estrada-Peña A, Horak I, et al. The Argasidae, Ixodidae and Nuttalliellidae (Acari: Ixodida) of the world: a list of valid species names. Zootaxa 2010; 2528(06):1-28.
11. Barandika JF, Hurtado A, Garcia-Sanmartin J, Juste RA, Anda P, Garcia-Perez AL. Prevalence of tick-borne zoonotic bacteria in questing adult ticks from northern Spain. Vector Borne Zoonotic Dis 2008; 8(6):82935.

12. Baneth G. Tick-borne infections of animals and humans: a common ground. Int J Parasitol 2014; 44(9):591-6.

13. Randolph SE. Tick-borne disease systems. Rev Sci Tech Off Int Epiz 2008; 27(2):1-15.

14. Mansfield $K L$, Johnson N, Phipps LP, Stephenson JR, Fooks AR, Solomon T. Tickborne encephalitis virus - a review of an emerging zoonosis. J Gen Virol 2009; 90(Pt 8):1781-94.

15. Slovak $M$, Kazimirova $M$, Siebenstichova $M$, Ustanikova K, Klempa B, Gritsun T, et al. Survival dynamics of tick-borne encephalitis virus in Ixodes ricinus ticks. Ticks Tick Borne Dis $2014 ; 5(6): 962-9$.

16. Estrada-Peña A, Ayllon N, de la Fuente J. Impact of climate trends on tick-borne pathogen transmission. Front Physiol 2012; 3(Mar):64.

17. Ndip RN, Ndive VE, Awuh JA, Walker DH, McBride JW. Ehrlichia species in Rhipicephalus sanguineus ticks in Cameroon. Vector Borne Zoonotic Dis 2007; 7(2):2217.

18. Reis C, Cote M, Paul RE, Bonnet S. Questing ticks in suburban forest are infected by at least six tick-borne pathogens. Vector Borne Zoonotic Dis 2011; 11(7):907-16.

19. Lommano E, Bertaiola L, Dupasquier C, Gern L. Infections and coinfections of questing Ixodes ricinus ticks by emerging zoonotic pathogens in Western Switzerland. Appl Environ Microbiol 2012; 78(13):4606-12.

20. Halos L, Bord S, Cotte V, Gasqui P, Abrial D, Barnouin J, et al. Ecological factors characterizing the prevalence of bacterial tick-borne pathogens in Ixodes ricinus ticks in pastures and woodlands. Appl Environ Microbiol 2010; 76(13):4413-20. 
21. Wormser GP, Dattwyler RJ, Shapiro ED, Halperin JJ, Steere AC, Klempner MS, et al. The clinical assessment, treatment, and prevention of lyme disease, human granulocytic anaplasmosis, and babesiosis: clinical practice guidelines by the Infectious Diseases Society of America. Clin Infect Dis 2006; 43(9):1089-134.

22. Piesman J, Eisen L. Prevention of tick-borne diseases. Annu Rev Entomol 2008; 53:32343.

23. Quintero JC, Hidalgo M, Rodas JD. Rickettsiosis, una enfermedad letal emergente y re-emergente en Colombia. Univ Sci 2012; 17(1):82-99.

24. Gilbert L. Altitudinal patterns of tick and host abundance: a potential role for climate change in regulating tick-borne diseases? Oecologia 2010; 162(1):217-25.

25. Perez $M$, Bodor $M$, Zhang C, Xiong Q, Rikihisa Y. Human infection with Ehrlichia canis accompanied by clinical signs in Venezuela. Ann N Y Acad Sci 2006; 1078:110-7.

26. Gray JS, Dautel H, Estrada-Pena A, Kahl $\mathrm{O}$, Lindgren $\mathrm{E}$. Effects of climate change on ticks and tick-borne diseases in europe. Interdiscip Perspect Infect Dis 2009; 2009:593232.

27. Althaus F, Greub G, Raoult D, Genton B. African tick-bite fever: a new entity in the differential diagnosis of multiple eschars in travelers. Description of five cases imported from South Africa to Switzerland. Int J Infect Dis 2010; 14 Suppl 3:e274-6.

28. Rovery C, Raoult D. Mediterranean spotted fever. Infect Dis Clin North Am 2008; 22(3):515-30, ix.

29. Contreras V, González M, Guzmán C, Máttar S. Fiebre Q: una zoonosis olvidada en Colombia. Rev Méd Risaralda. 2013; 19(2):137-46.

30. Brackney MM, Marfin AA, Staples JE, Stallones L, Keefe T, Black WC, et al. Epidemiology of Colorado tick fever in Montana, Utah, and Wyoming, 1995-2003. Vector Borne Zoonotic Dis $2010 ; 10(4): 381-5$.

31. Ergonul O. Crimean-Congo haemorrhagic fever. Lancet Infect Dis 2006; 6(4):203-14.
32. Liu Q, He B, Huang SY, Wei F, Zhu XQ. Severe fever with thrombocytopenia syndrome, an emerging tick-borne zoonosis. Lancet Infect Dis 2014; 14(8):763-72.

33. Gray J, Zintl A, Hildebrandt A, Hunfeld KP, Weiss L. Zoonotic babesiosis: overview of the disease and novel aspects of pathogen identity. Ticks Tick Borne Dis 2010; 1(1):3-10.

34. Dantas-Torres F, Chomel BB, Otranto D. Ticks and tick-borne diseases: a One Health perspective. Trends Parasitol 2012; 28(10):437-46.

35. Mills JN, Gage KL, Khan AS. Potential influence of climate change on vectorborne and zoonotic diseases: a review and proposed research plan. Environ Health Perspect 2010; 118(11):1507-14.

36. Ostfeld RS, Levi T, Jolles AE, Martin LB, Hosseini PR, Keesing F. Life history and demographic drivers of reservoir competence for three tick-borne zoonotic pathogens. PLoS One 2014; 9(9):e107387.

37. Burri C, Bastic V, Maeder G, Patalas E, Gern L. Microclimate and the zoonotic cycle of tick-borne encephalitis virus in Switzerland. J Med Entomol 2011; 48(3):615-27.

38. Molin $Y$, Lindeborg $M$, Nystrom $F$, Madder M, Hjelm E, Olsen B, et al. Migratory birds, ticks, and Bartonella. Infect Ecol Epidemiol $2011 ; 1: 5997$.

39. Palomar AM, Santibanez $P$, Mazuelas D, Roncero L, Santibanez S, Portillo A, et al. Role of birds in dispersal of etiologic agents of tick-borne zoonoses, Spain, 2009. Emerg Infect Dis 2012; 18(7):1188-91.

40. Hornok S, Kováts D, Csörgő $T$, Meli ML, Gönczi E, Hadnagy Z, et al. Birds as potential reservoirs of tick-borne pathogens: first evidence of bacteraemia with Rickettsia helvetica. Parasit Vectors 2014; 7:128.

41. Cabello C, Cabello F. Zoonosis con reservorios silvestres: Amenazas a la salud pública y a la economía. Rev Méd Chile 2008; 136(3):385-93.

42. Kilpatrick AM, Randolph SE. Drivers, dynamics, and control of emerging vectorborne zoonotic diseases. Lancet 2012; 380(9857): 1946-55. 
43. Godfrey ER, Randolph SE. Economic downturn results in tick-borne disease upsurge. Parasit Vectors 2011; 4:35.

44. Fenollar F, Raoult D. Molecular diagnosis of bloodstream infections caused by noncultivable bacteria. Int J Antimicrob Agents 2007; 30(Suppl. 1): 7-15.

45. Fuentes $M$, Pérez $L$, Suárez $Y$, Soca $M$, Martínez A. La zoonosis como ciencia y su impacto social. Rev Electr Vet 2006; 7(9): 1-19.
46. De Meneghi D. Wildlife, environment and (re)-emerging zoonoses, with special reference to sylvatic tick-borne zoonoses in North-Western Italy. Ann Ist Super Sanita 2006; 42(4):405-9.

47. Ahmed J, Bouloy M, Ergonul O, Fooks A, Paweska J, Chevalier V, et al. International network for capacity building for the control of emerging viral vector-borne zoonotic diseases: ARBO-ZOONET. Euro Surveill 2009; 14(12. 1-4.).

48. Piesman J, Beard CB. Prevention of tickborne diseases. J Environ Health 2012; 74(10):30-2. 